\title{
Studies on Lipid Peroxides and the Enzymes Which Are Involved in Their Production in Taro Tubers Infected by Ceratocystis fimbriata
}

\author{
Hironori MaSui*, Mioko NAKAYAma* and Masaru OHTURU*
}

\begin{abstract}
Two enzymes, Lipoxygenase (LOX) and lipid hydroperoxide converting enzyme (LHCE), which are responsible for the production of antifungal lipid peroxides, were detected in taro tubers infected by Ceratocystis fimbriata. The infected taro tubers contained two LOX isozymes (LOX-1, LOX.2). The main isozyme of LOX was LOX-2 that showed optimal activity at pH 5.5. The enzyme (LOX-2) showed similar magnitude of activity toward linoleic acid (100\%) and linolenic acid $(77 \%)$, but did not show any activity toward methyl linoleate $(0 \%)$. It changed linoleic acid into 9- (9-LOOH) and 13-linoleate hydroperoxides (13- $\mathrm{LOOH})$ in the ratio of $47: 53$. The infected taro tubers contained two isozymes of LHCE (LHCE-1, LHCE-2) with similar substrate specificity. When 9- or 13-LOOH of linoleic acid was used as the substrate of LHCE, main product was 9- or 13-hydroxyoctadecadienoic acid ( $\mathrm{LOH}$ ), respectively. 9,12,13-trihydroxyoctadecenoic acid $(9,12,13$ $\mathrm{LOH})$ was produced as a minor product from 9-LOOH by LHCE. All of 9- and 13-LOOH, 9- and 13-LOH, and 9,12,13-LOH showed the similar toxicity toward both sweet potato and taro strains of $C$. fimbriata. On the other hand, the crude enzyme preparation (containing both LOX and LHCE) from the infected taro tubers converted linolenic acid into the peroxides compound(s), which inhibited the growth of sweet potato strain more severely than that of taro strain.
\end{abstract}

(Received December 30, 1992)

Key words: lipoxygenase, lipid hydroperoxide converting enzyme, taro, Ceratocystis fimbriata, antifungal compound.

\section{INTRODUCTION}

Various strains of Ceratocystis fimbriata have been isolated from black rot lesions on various plants such as taro and sweet potato. These strains show strict host specificity. Taro strain is pathogenic to taro but not to sweet potato, while sweet potato strain is pathogenic to sweet potato, but not to taro.

It has been reported with some plant host-parasite interactions that lipid peroxidation takes place in the early stage of infection and that the lipid peroxides produced in plants play the important roles in inhibiting the growth of invading parasite ${ }^{-4,6,9,13-15,17)}$. We previously isolated 9,12,13-trihydroxy-(E)10-octadecenoic acid $(9,12,13-\mathrm{LOH})$ as an antifungal compound from taro tubers inoculated by $C$. fimbriata ${ }^{7)}$. The structure of $9,12,13-\mathrm{LOH}$ suggests that it is synthesized in vivo by following mechanisms; linoleic or linolenic acid was first peroxided into hydroperoxide derivatives by lipoxygenase (LOX). Subsequently, the hydroperoxide derivatives are changed into hydroxy fatty acid by lipid hydroperoxide converting enzyme (LHCE). LOX is a ubiquitous enzyme in higher plants ${ }^{16)}$. Recently LHCE was detected in rice leaves infected by blast fungus and characterized by Ohta et al. ${ }^{10,11)}$

In this paper, we report detection and properties of LOX and LHCE in the taro tubers infected by

\footnotetext{
* Faculty of Home Economics, Yamaguchi Women's University, 3 2-1. Sakurabatake, Yamaguchi 753, Japan
} 山口女子大学家政学部 
C. fimbriata. In addition, we report the antifungal activity of lipid peroxides produced by the enzymes toward C. fimbriata.

\section{MATERIALS AND METHODS}

Chemicals. Lipoxygenase (from soybean, type I) was purchased from Sigma Chemical Co. DEAE-Toyopearl M-650 and Sephadex G-25 were from Toyo Soda Co. (Tokyo) and Pharmacia Fine Chemicals (Uppsala, Sweden), respectively. Trimethylsilyation reagent, Tri-sil, was obtained from PIERCE (Rockford, USA). All other chemicals were of reagent grade.

Preparation of inoculum. Taro and sweet potato strains of $C$. fimbriata were used. Inoculum $\left(7 \times 10^{6}\right.$ spores $\left./ \mathrm{ml}\right)$ was prepared by the method of Kojima et al. $\left.{ }^{5}\right)$

Preparation of taro tuber disks and inoculation. Taro tuber disks $(1.2 \times 0.2 \mathrm{~cm})$ were prepared and were rinsed in distilled water to remove the latex from the surface. The rinsed disks were blotted with filter paper and incubated at $25^{\circ} \mathrm{C}$ for $25 \mathrm{hr}$ in a moist chamber after inoculation with sweet potato or taro strain.

Preparation of peroxides of linolenic acid. The crude enzyme including both LOX and LHCE was prepared from the taro tubers incubated for $25 \mathrm{hr}$ after inoculation by the method described below. The enzyme solution ( $10 \mathrm{ml}, 2,000$ units of LOX) was added to $20 \mathrm{ml}$ of the solution containing $39 \mathrm{mg}$ of linolenic acid in $0.1 \mathrm{M}$ citrate- $\mathrm{Na}_{2} \mathrm{HPO}_{4}$ buffer, $\mathrm{pH} 5.5$ and shaked at $25^{\circ} \mathrm{C}$. After $12 \mathrm{hr}$ shaking, $100 \mu \mathrm{l}$ of conc. $\mathrm{HCl}$ was added to the reaction mixture and extracted with diethyl ether. The ether fraction was dried up under $\mathrm{N}_{2}$. The remained solid material was used as peroxides of linolenic acid for assay of antifungal activity.

Preparation of 9- and 13-hydroperoxy linolenic acids. 9-LOOH was prepared using potato lipoxygenase by following method. Crude potato lipoxygenase was prepared by the method of Sekiya et al. ${ }^{12)}$ Potato lipoxygenase $(6,300$ units) was added to $450 \mathrm{ml}$ of $5 \mathrm{mM}$ linoleic acid in $0.1 \mathrm{M}$ acetate buffer, pH 5.5 containing $0.07 \%$ Tween 20 and incubated for $1 \mathrm{hr}$ at $25^{\circ} \mathrm{C}$ by stirring and bubbling $\mathrm{O}_{2}$. Then the reaction mixture was adjusted at $\mathrm{pH} 4.0$ with conc. $\mathrm{HCl}$ and extracted with diethyl ether. The extract was condensed and subjected to TLC of slica using a solvent ( $n$-hexane : diethyl ether : acetic acid $=10: 5: 0.1)$. 9-LOOH was visualized under UV light and were scrapped off the silica gel plates and extracted with chloroform : methanol $=2: 1$. The extract was passed through a Ekicrodisc filter (Gelman Sciences Japan, Ltd.) to remove the silica gel powder and concentrated under $\mathrm{N}_{2}$.

13-LOOH was prepared using commercial soybean lipoxygenase as follows. Linoleic acid $(1 \mathrm{~g})$ was suspended in $30 \mathrm{ml}$ of $0.1 \%$ Tween 20 and $1 \mathrm{~N} \mathrm{NaOH}$ was added until the suspension became a clear solution. Then $400 \mathrm{ml}$ of $0.1 \mathrm{M}$ borate buffer $(\mathrm{pH} 9.0)$ and soybean lipoxygenase $(10 \mathrm{mg}$ ) were added to the linoneic acid solution and incubated by stirring and bubbling $\mathrm{O}_{2}$ at $0^{\circ} \mathrm{C}$ for $1 \mathrm{hr}$. After incubation, 13- $\mathrm{LOOH}$ was isolated from the reaction mixture by the same method as that used for 9-LOOH.

Both of 9- and 13-LOOH prepared as described above were purified further using a HPLC (LiChrospher Si $60(4 \mathrm{~mm}$ i.d. $\times 250 \mathrm{~mm}$, Cica-MERCK), solvent system; $n$-hexane containing $2.5 \%(\mathrm{v} / \mathrm{v})$ isopropyl alcohol and $0.2 \%(\mathrm{v} / \mathrm{v})$ acetic acid). The purified 9- and $13-\mathrm{LOOH}$ were stored as ethanol solution at $-20^{\circ} \mathrm{C}$ and used within a month.

9. or 13-hydroxy of linolenic acid was prepared from 9- or 13-LOOH, respectively, by reducing with $\mathrm{NaBH}_{4} \cdot 9,12,13$-Octadecenoic acid was purified as described in our preceding paper ${ }^{7}$.

Extraction and assay of LOX and LHCE. Five disks $(1.2 \times 0.2 \mathrm{~cm})$ were ground in $5 \mathrm{ml}$ of $0.1 \mathrm{M}$ Tris- $\mathrm{HCl}$ buffer ( $\mathrm{pH} 7.5$ ) containing $0.1 \%$ Tween 20 and sea sand using mortar and pestle and the homogenate was stood at $4^{\circ} \mathrm{C}$ for $1 \mathrm{hr}$. Subsequently, the homogenate was centrifuged at $43,700 \times \mathrm{g}$ for $15 \mathrm{~min}$ at $4^{\circ} \mathrm{C}$. The resultant supernatant was applied to a column $(4.6 \times 16 \mathrm{~cm})$ of Sephadex G-25. The void volume fraction was used for assay of both LOX and LHCE.

The activity of LOX was assayed with spectrophotometrical procedure in our preceding paper ${ }^{81}$ and one unit of LOX was defined as the amount of the enzyme that produce one $\mu \mathrm{mol}$ of lipid hydroperoxide per min under the assay conditions.

LHCE activity was assayed by the method of Ohta et al. ${ }^{11}$ One unit of the activity was expressed 
as the amount of the enzyme that causes disappearance of one $\mu$ mol of hydroperoxy octadecadienoic acid per min at $25^{\circ} \mathrm{C}$ under the assay conditions.

DEAE-Toyopearl column chromatography. The inoculated taro tuber silices after incubated for $25 \mathrm{hr}(80 \mathrm{~g})$ was ground in $80 \mathrm{ml}$ of TTG buffer $(0.1 \mathrm{Tri} \cdot \mathrm{HCl}$ buffer $(\mathrm{pH} 7.5)$ with $0.1 \%$ Tween 20 and $10 \%(\mathrm{v} / \mathrm{v})$ glycerol), including iso-ascorbic acid $(0.8 \mathrm{~g})$ and sea sand in a mortar. The homogenate was stood at $4^{\circ} \mathrm{C}$ for $1 \mathrm{hr}$, squeezed through 4 layers of gauze and centrifuged at $43,700 \times \mathrm{g}$ for $15 \mathrm{~min}$. The supernatant was passed through a Sephadex G.25 column and the effluent fraction was collected. The fraction was condensed by filtration through Amicon YM-10 filter and then applied to a column $(2.3 \times$ $10 \mathrm{~cm}$ ) of DEAE-Toyopearl pre-equilibrated with TTG buffer. The column was washed with TTG buffer, and then eluted with $200 \mathrm{ml}$ of a linear gradient of 0 to $0.3 \mathrm{M} \mathrm{NaCl}$ in TTG buffer. Every $3.8 \mathrm{ml}$ was collected and assayed for LOX and LHCE activities and protein content.

Preparation and identification of LOX reaction products. LOX-2 after DEAE-Toyopearl column chromatography ( 30 units) was added to $10 \mathrm{ml}$ of $2 \mathrm{mM}$ linoleic acid in $0.1 \mathrm{M}$ acetate buffer, $\mathrm{pH}$ 5.5 , containing $0.1 \%$ Tween 20 and incubated at $25^{\circ} \mathrm{C}$ for $20 \mathrm{~min}$. The reaction products were extracted with diethyl ether and condensed under $\mathrm{N}_{2}$. The remained substances were dissolved in ethanol and applied to HPLC. The peak of each product was collected and methylated with $\mathrm{CH}_{2} \mathrm{~N}_{2}$ and subsequently trimethylsilyated with Tri-Sil. The samples thus prepared were analyzed by Shimadzu GCMSQP11000EX system with $2 \%$ OV -17 glass column; (tem.operation $160-240^{\circ} \mathrm{C}, 3^{\circ} \mathrm{C} / \mathrm{min}$. ion source $250^{\circ} \mathrm{C}$, in let $20 \mathrm{eV}$.)

Preparation and identification of LHCE reaction products. $\quad 9-$ or $13-\mathrm{LOOH}(5 \mathrm{mg})$ in $0.1 \mathrm{M}$ phosphate buffer, pH 5.5 was incubated with 5 units of LHCE after DEAE-Toyoperl column chromatography at $25^{\circ} \mathrm{C}$ for $20 \mathrm{~min}$. The reaction products were extracted with chloroform : methanol $(2: 1)$. Subsequently, products were purified by HPLC and analyzed by the same procedures as that for the products of LOX described above.

Analytical data ; Reaction products of 9-LOOH ; (1) methyl and trimethylsilyated product of 9-LOH, $m / z 382[\mathrm{M}](16.8) 225[\mathrm{M}-157](71.2) 130[\mathrm{M}-252](38) 73[\mathrm{M}-309](100)$ (2) methyl and trimethylsilyated product of 9,12,13-LOH, $m / z$ 461(14) 387[M-173](16) 259(56) 173[M-387](100).

Reaction products of $13-\mathrm{LOOH}$; (1) methyl and trimethylsilyated product of $13-\mathrm{LOH}, \mathrm{m} / z 382$ [M] (18) 311[M-71](52) $130[\mathrm{M}-252](51.2)$ 73[M-309](100).

Bioassay of antifungal activity. Antifungal activity of lipid peroxide were assayed as described in our preceding paper ${ }^{7)}$.

\section{RESULTS}

\section{LOX in the infected taro tubers}

LOX was extracted from taro tuber slices which were incubated for $25 \mathrm{hr}$ after inoculation with

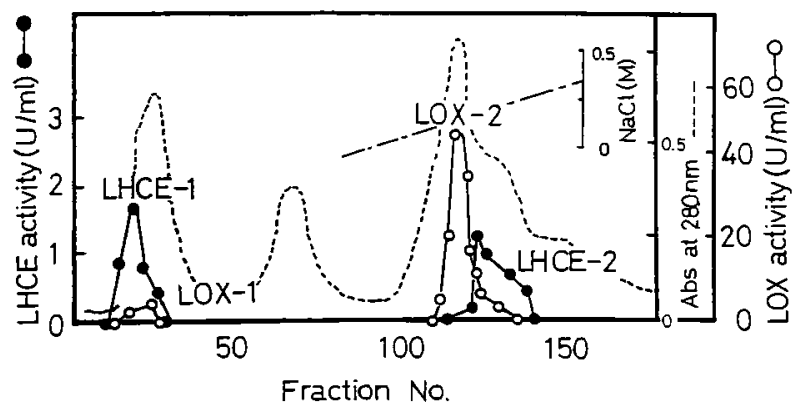

Fig. 1. Elution profiles of LOX and LHCE from taro strain-infected taro tubers on DEAE-Toyopearl column chromatography. Experimental conditions are described in the texts. LOX activity, LHCE activity, $\cdots$ Abs. 280 . 


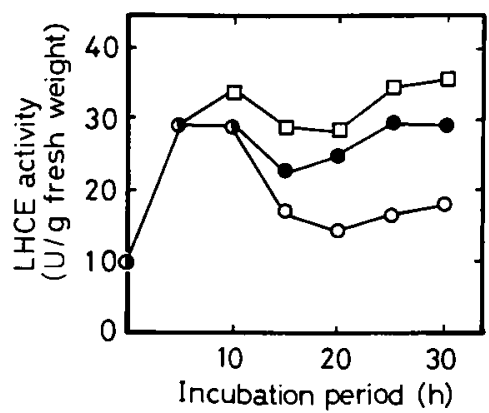

Fig. 2. Change in LHCE activity after inoculation. Experimental conditions are described in the texts. $\square$ : inoculated with taro strain, : inoculated with sweet potato strain, $\sigma$ : wounded (no inoculation).

Table 1. Antifungal activity of 9-hydroperoxy (9-LOOH) and 13-hydroperoxy (13-LOOH) of linoleic acids against taro and sweet potato strains of $C$. fimbriata

\begin{tabular}{ccccc}
\hline \hline \multirow{2}{*}{$\begin{array}{c}\text { Concentration of } \\
\text { LOOH (mM) }\end{array}$} & \multicolumn{3}{c}{ Taro strain } & \multicolumn{2}{c}{ Relative germ tube growth } \\
\cline { 2 - 5 } & $9-\mathrm{LOOH}$ & 13-LOOH & 9-LOOH & 13-LOOH \\
\hline 21.1 & 0 & 0 & 0 & 0 \\
10.6 & 0 & 0 & 0 & 0 \\
5.3 & +1 & +1 & +1 & +1 \\
2.6 & +1 & +1 & +1 & +3 \\
1.0 & +3 & +3 & +5 & +3 \\
0 & +5 & +5 & +5 & +5 \\
\hline
\end{tabular}

a) Relative germ tube growth was denoted by arbitrary scale. Zero indicated no germination.

taro strain of $C$. fimbriata, and analyzed by DEAE-Toyopearl column chromatography (Fig. 1). To peaks of LOX, (LOX-1 and LOX-2) were detected. The main component of LOX in infected taro tubers was LOX-2. LOX-2 showed optimal activity at $\mathrm{pH}$ 5.5. It showed the similar magnitude of activity toward linoleic acid (100\%) and linolenic acid $(77 \%)$ but not any activity toward methyl linoleate $(0 \%)$. It converted linoleic acid into 9-hydroperoxy linoleic acid (9-LOOH) and 13-LOOH in the ratio of $47: 53$.

\section{Induction of LHCE in inoculated taro tubers}

LHCE activity was detected in fresh taro tubers and increased during the initial $10 \mathrm{hr}$, then decreased for the next $10 \mathrm{hr}$ and finally increased again in non-inoculated (wounded) taro tubers during incubation (Fig. 2). LHCE activity was also changed in the tubers inoculated by taro or sweet potato strains in similar pattern to that in wounded tubers. However the magnitude of the changes in taro strain inoculated tubers was larger comparing with in sweet potato strain inoculated tubers and in wounded tubers.

\section{Identification of reaction products of $\mathrm{LHCE}$}

The reaction products of LHCE with 9-LOOH and 13-LOOH as substrate were identified by using HPLC and GC-MS as described in MATERIAL and METHODS. The products showed the same Mass spectra as those of products prepared by Ohta et al. ${ }^{11}$ The products with 9.LOOH were 9-hydroxy linoleic acid (9-LOH) as a main product and 9,12,13-trihydroxy linoleic acid $(9,12,13-\mathrm{LOH})$ as a minor product. A main product with $13-\mathrm{LOOH}$ was $13-\mathrm{LOH}$.

\section{Antifungal activities of hydroperoxy and hydroxy linoleic acids}

No difference was observed in antifungal activity between 9-LOOH and 13-LOOH (Table 1). In addition, both LOOHs did not show differential toxicity toward sweet potato and taro strains (Table 1). There was also no difference in antifungal activity between 9-LOH and 13-LOH (Tables 1 and 2). 9-LOH and 13-LOH showed the similar magnitude of antifungal activity toward both strains (Table 2). 9,12. 13- LOH also showed a similar magnitude of antifugal activity against both strains (Table 3). 
Table 2. Antifungal activity of 9-hydroxy (9-LOH) and 13-hydroxy (13-LOH) of linoleic acids against taro and sweet potato strains of $C$. fimbriata

\begin{tabular}{ccccc}
\hline \multirow{2}{*}{$\begin{array}{c}\text { Concentration of } \\
\text { LOOH (mM) }\end{array}$} & \multicolumn{4}{c}{ Relative germ tube growth } \\
\cline { 2 - 5 } & $9-\mathrm{LOH}$ & Taro strain & \multicolumn{2}{c}{ Sweet potato strain } \\
21.1 & 0 & $13-\mathrm{LOH}$ & 9-LOH & 13-LOH \\
10.6 & 0 & 0 & 0 & 0 \\
5.3 & +1 & 0 & 0 & +1 \\
2.6 & +3 & +1 & +3 & +3 \\
1.0 & +5 & +3 & +5 & +5 \\
0 & +5 & +5 & +5 & +5 \\
\hline
\end{tabular}

a) Relative germ tube growth was denoted by arbitrary scale. Zero indicated no germination.

Table 3. Antifungal activity of 9,12,13-octadecenoic acid $(9,12,13 \cdot \mathrm{LOH})$ against taro and sweet potato strains of C. fimbriata

\begin{tabular}{|c|c|c|}
\hline \multirow{2}{*}{$\begin{array}{l}\text { Concentration of } \\
9,12,13-\mathrm{LOH}(\mathrm{mM})\end{array}$} & \multicolumn{2}{|c|}{ Relative germ tube growth ${ }^{\text {n' }}$} \\
\hline & Taro strain & Sweet potato strain \\
\hline 9.1 & 0 & 0 \\
\hline 7.6 & +2 & +2 \\
\hline 6.1 & +2 & +2 \\
\hline 3.0 & +8 & +8 \\
\hline 1.5 & +8 & +8 \\
\hline 0 & +8 & +8 \\
\hline
\end{tabular}

a) Relative germ tube growth was denoted by arbitrary scale. Zero indicated no germination.

Table 4. Antifungal activity of the mixture of peroxides of linolenic acid produced by crude enzymes (includes LOX and LHCE) from taro strain-inoculated taro tubers against taro and sweet potato strains of C. fimbriata

\begin{tabular}{|c|c|c|}
\hline \multirow{2}{*}{$\begin{array}{c}\text { Concentration of } \\
\text { linolenic acid } \\
(\mathrm{mM})\end{array}$} & \multicolumn{2}{|c|}{ Relative germ tube growtha) } \\
\hline & Taro strain & Sweet potato strain \\
\hline 56 & +0.5 & 0 \\
\hline 42 & +3 & 0 \\
\hline 28 & +4 & +1 \\
\hline 14 & +5 & +1 \\
\hline \multicolumn{3}{|l|}{ Controls ${ }^{c \mid}$} \\
\hline active enzyme only & +10 & +10 \\
\hline linolenic acid only & +10 & +10 \\
\hline boiled enzyme only & +10 & +10 \\
\hline boiled enzyme and linolenic acid & +8 & +8 \\
\hline
\end{tabular}

a) Relative germ tube growth was denoted by arbitrary scale. Zero indicated no germination.

b) The germ tube growth was examined in the assay mixture containing the linolenic acid at the concentrations indicated and enzyme preparation.

c) In controls, assays were carried out in the mixtures containing active enzyme only, linolenic acid (56 mM) only, boiled enzyme only or boiled enzyme and linolenic acid $(56 \mathrm{mM})$

Differential antifungal activity of mixtures of linolenic acid peroxides toward two strains Linolenic acid was peroxidized by the crude enzyme from infected taro tubers which contained both LOX and LHCE. HPLC analysis indicated that the reaction product contained several unknown products in addition to 9- $\mathrm{LOOH}, 13-\mathrm{LOOH}, 9 \cdot \mathrm{LOH}, 13-\mathrm{LOH}$ and $9,12,13-\mathrm{LOH}$ (data not shown). The peroxidized linolenic acid thus prepared showed differential toxicity toward taro and sweet potato strains; $42 \mathrm{mM}$ of the mixture inhibited completely germ tube growth of sweet potato strain, while it inhibited moderately that of taro strain (Table 4). 


\section{DISCUSSION}

The present study demonstrated that taro tubers infected by $C$. fimbriata contained LOX and LHCE. The two enzymes, LOX and LHCE, converted, in vitro, linolenic acid into 9, 12,13-trihydroxyoctadecenoic acid, which was isolated as one of antifungal compounds from the infected taro tubers in our preceding paper ${ }^{7}$. LHCE in the infected taro tubers was very similar to the enzymes in rice leaves reported by Ohta $e t a l .^{11}$ Both taro tubers and rice leaves contained two isozymes. Both enzymes from two plants converted linolenic acid into the same peroxides.

LHCE activity changed in the similar pattern in three taro tuber samples; wounded, sweet potato strain-infected and taro strain-infected taro tuber disks (Fig. 2). Activity increased during the initial 10 $\mathrm{hr}$, and decreased during the next $10 \mathrm{hr}$. Finally the activity increased again. Only slight difference was observed in the activity of the first peak at $10 \mathrm{hr}$ after inoculation among the three taro tuber samples. Subsequently, the difference in the activity in three samples became largers; the activity in taro strain infected tubers was the highest and the activity in wounded tubers was the lowest. Such induction pattern of LHCE suggested that the increased activity during the initial $10 \mathrm{hr}$ was due to wounding and the subsequent change was due to infection.

As mentioned above, LHCE activity at second peak in taro strain infected tuber disks was higher than that in sweet potato strain infected tuber disks. This result is consistent with the results of time course analysis of lipid peroxide accumulation in taro tubers infected by the two strains; more lipid peroxides were accumulated in the taro tuber disks infected by taro strain than in the taro tuber disks infected by sweet potato strains ${ }^{8}$. One possible explanation for the differences in LHCE activity and lipid peroxide accumulation in taro tuber disks infected by the two strains might be that taro strain invade into more inner cells in the disks than sweet potato strain.

LOX and LHCE produced various peroxides from linolenic acid; 9-LOOH 13-LOOH, 9-LOH, 13- $\mathrm{LOH}$ and 9,12,13-LOH. We examined antifungal activity of the above peroxides separately (Tables 1-3). All peroxides showed strong antifungal activity. However, there was no difference in toxicity among them. In addition, they inhibited similarly the growth of sweet potato and taro strains of $C$. fimbriata. The results were in contrast to the result by Ohta et al. that 9-LOH was more toxic to Magnaporthe grisea than 9-LOOH.

Differential toxicity was demonstrated with linolenic acid peroxidized by the crude enzymes from infected taro tubers which contained both LOX and LHCE (Table 4). Sweet potato strain was inhibited more severely than taro strain. This result apparently is contradiction to the results in Table 1,2 and 3. which indicated that individual peroxide of linolenic acid such as 9-LOOH, 13-LOOH, 9-LOH, 13-LOH and 9,12,13-LOH did not show differential toxicity. There are some possible explanation for the contradiction. The unknown oxidized products included in the peroxidized linolenic acid fraction might be responsible for differential toxicity. Alternatively, the mixture of individual peroxide might show differential toxicity.

The present paper demonstrated definitely the occurrence of LOX and LHCE which are involved in production of lipid peroxides. The lipid peroxides produced by the enzymes had antifungal activity. The activity of LHCE increased in taro tubers in response to infection by $C$. fimbriata. These results suggest that these enzymes and their products, namely, lipid peroxides play role in the host defense reaction.

\section{Literature cited}

1. Kato, Y., Yamaguchi, T., Uyehara, T., Yokoyama, T., Namia, T. and Yamanaka, S. (1983). Defense mechanism of the rice plant against rice blast disease. Naturwissenschaften $70: 200-201$.

2. Keppler. L.D. and Novacky. A. (1986). Involvement of membrane lipid peroxidation in the development of bacterially induced hypersensitivity reaction. Phytopathology $76: 104-108$.

3. Keppler. L.D. and Novacky, A. (1987). The initiation of membrane lipid peroxidation during bacteriainduced hypersensitivity reaction. Physiol. Plant Pathol. $30: 233-245$.

4. Keppler, L.D. and Novacky, A. (1989). $\mathrm{O}_{2}^{-}$-Initiated lipid peroxidation in a bacteria-induced hypersen- 
sitivity reaction in tobacco cell suspensions. Phytopathology $79: 555-562$.

5. Kojima, M. and Uritani, I. (1974). The possible involvement of a spore agglutinating factor(s) in various plants in establishing host specificity by various strains of black rot fungus, Ceatocystis fimbriata. Plant Cell Physiol. 15 : 733-737.

6. Li, W.X., Kodama, O. and Akatuka, T. (1991). Role of oxygenated fatty acids in rice phytoalexin production. Agric. Biol. Chem. 55 : 1041-1047.

7. Masui, H., Kondo, T., and Kojima, M. (1989). An antifungal compound 9,12,13-trihydroxy-(E)-10octadecenoic acid, from Colocasia antiquonem inoculated with Ceratocystis fimbriata. Phytochemistry 28 : 2613-2615.

8. Masui, H. and Kojima, M. (1990). Lipid peroxidation and its role in taro tubers infected by Ceratocystis fimbriata. Agric. Biol. Chem. 54 : 1689-1695.

9. Namai, T., Kato, T., Yamaguchi, Y. and Togashi, J. (1991). Cytotoxicity and anti-blast activity of hydroperoxide of linolenic acid produced by in vitro enzyme reaction using blast-infected rice leaves. Ann. Phytopath. Soc. Japan. $57: 339-344$.

10. Ohta, H., Shida, K., Peng, Y.L., Furusawa. I., Shishiyama, J., Aibara, S. and Morita, Y. (1991). A lipoxy. genase pathway is activated in rice after infection with the rice blast fungus Magnaporthe grisea. Plant Physiol. $97: 94-98$.

11. Ohta, H., Shida, K., Peng, Y.L., Furusawa, I., Shishiyama, J., Aibara, S. and Morita, Y. (1990). The occurrence of lipid hydroperoxide-decomposing activities in rice and the relationship of such activities to the formation of antifungal substances. Plant Cell Phyiol. $31 ; 1117-1122$.

12. Sekiya, J., Adashima, H., Kajiwara, T., Tago, T. and Hatanaka, A. (1977). Purification and some properties of potato tuber lipoxygenase and detection of linoleic acid radical in the enzyme reaction. Agric. Biol. Chem. $41: 827-832$.

13. Sekizawa, Y., Shimura, M., Suzuki, A. and Iwata, M. (1981). Anti-conidial germination factors induced in the presence of probenazole in infected host leaves. II. Structural elucidation of the major component (substance B). Agric. Biol. Chem. 45: 1437-1439.

14. Shimura, M., Iwata, M., Tashiro, N., Sekizawa, Y., Suzuki, Y., Mase, S. and Watanabe, T. (1981). Anti-conidial germination factors induced in the presence of probenazole in infected host leaves. I. Isolation and properties of four active substances. Agric. Biol. Chem. $45: 1431-1435$.

15. Shimura, M., Mase, S., Iwata, M., Suzuki, A., Watanabe, T., Sekizawa, Y., Sasaki, T., Furihata, K., Seto, H. and Otake, N. (1983). Anti-conidial germination factors induced in the presence of probenazole in infected host leaves. III. Structural elucidation of substances A and C. Agric. Biol. Chem. 47: 1983-1989.

16. Vick, B.A. and Zimmerman, D.C. (1987). Oxidative systems for modification of fatty acid : the lipoxygenase pathway. In Biochemistry of Plants-Comprehensive Treatise (P.K. Stumpf., ed.) Vol. 9, Academic Press, New York. pp. 53-90.

17. Yamamoto, H. and Tani, T. (1991). In Recent Advances in Physiological Plant Pathology. The Publishing Committee of Recent Advances in Physiological Plant Pathology, Nagoya. pp. 115-124 (in Japanese).

\section{和 文 摘 要}

升井洋至・中山実生子・大鶴 勝：Ceratocystis fimbriata 感染サトイモに括ける過酸化脂質生成とその生成に関与す る酵素に関する研究

抗菌活性をもつ過酸化脂質の生成に関与する lipoxygenase (LOX) と lipid hydroperoxide converting enzyme (LHCE)が C. fimbriata 感染サトイモ中に検出された。感染サトイモ中には 2 つ0 LOX (LOX-1, LOX-2)が含まれて いた。LOX-2が主要酵素であり，至適 $\mathrm{pH}$ は 5.5 で, linolenic acid と linoleic acid に対してほほ同し活性を示した。 本酵素は linoleic acidをほ济同量の9-hydroperoxy linoleic acid (9-LOOH) と 13-hydroperoxy linoleic acid

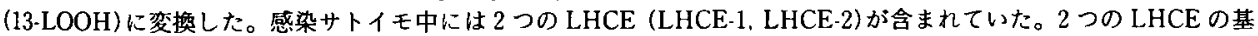
質特異性は同じで, 9-LOOH と 13-LOOH をそれそれ 9-hydroxy octadecenoic acid (9-LOH) と 13-hydroxy octadecenoic acid (13-LOH)に桨換した。9,12,13-trihydroxy octadecenoic acid (9,12,13-LOH)も 9-LOOH より LHCE

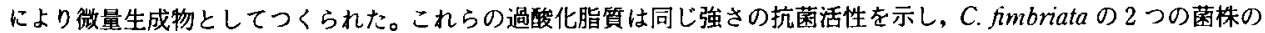
生育を同じ程度に阻害した。一方，感染サトイモより調製した粗醉素淮（LOX と LHCEを含む）を linolenic acidに作 用させてできた過酸化脂質は C. fimbriata のサツマイモ菌株をサトイモ菌株よりも強く阻害した。 